\title{
Nurses's knowledge and attitude in facing potential landslide disasters
}

\author{
Dwi Wahyu Sani S Karenhadi' ${ }^{1}$ Indah Dwi Pratiwi', Risa Herlianita1, \\ Indri Wahyuningsih ${ }^{1}$ \\ 1 Departemen Keperawatan, Fakultas Ilmu Kesehatan, Universitas Muhammadiyah Malang, Indonesia
}

\begin{tabular}{|c|c|}
\hline Article Info & Abstract \\
\hline $\begin{array}{l}\text { Article History: } \\
\text { Submitted: Nov 20th }, 2020 \\
\text { Accepted: Oct 19th, } 2021 \\
\text { Published: Nov 25th }, 2021 \\
\text { Keywords: } \\
\text { Knowledge; Attitude; } \\
\text { Nurses; Landslide; Disasters }\end{array}$ & $\begin{array}{l}\text { Landslide is one of the natural disasters which cause not only infrastructure } \\
\text { damage but also death. Nurses have a role in disaster management at the } \\
\text { phase of mitigation to rehabilitation during landslide disasters. This study } \\
\text { is aimed to analyze nurses' knowledge and attitudes in the face of future } \\
\text { landslide disasters. A quantitative method with a descriptive design was } \\
\text { used in the study. The respondents in this study were } 20 \text { nurses who work } \\
\text { at one rural community health center in Malang. Data were collected using a } \\
\text { questionnaire. From the current research, most respondents had been } \\
\text { involved in disaster emergency response activities (85\%), had good } \\
\text { knowledge ( } 75 \%) \text {, and all nurses (100\%) had a positive attitude towards } \\
\text { landslide disaster preparedness. From this current study, nurses' knowledge } \\
\text { and attitudes towards preparedness for facing landslides might be essential } \\
\text { to build more awareness among nurses in preparing the community in facing } \\
\text { landslides; thus, the impact of the disaster could be decreased. }\end{array}$ \\
\hline
\end{tabular}

\section{PENDAHULUAN}

Wilayah Indonesia rentan terhadap berbagai jenis bencana. Letusan gunung api, gempa bumi, tsunami, banjir dan tanah longsor merupakan bencana yang kerap kali terjadi di Indonesia [1,2]. Indonesia terkenal dengan lokasinya yang berada di ring of fire. Hal ini dikarenakan secara geografis dan geologis, letak Indonesia yang berada di atas lempeng tektonik di seluruh kepulauan Indonesia dengan kegiatan sistemik yang menyebabkan Indonesia menjadi rentan terhadap gempa bumi, banjir, tanah longsor, tsunami, dan berbagai bentuk bencana alam lainnya $[1,3]$.

Kejadian bencana tanah longsor merupakan kejadian terbanyak selama tahun 2016 di wilayah Kabupaten Malang. Menurut catatan Badan Penanggulangan Bencana Daerah (BPBD) Kabupaten Malang, dari total 56 kejadian bencana sebanyak 38 bencana tanah longsor terjadi selama 2016 [4]. Daerah di Kabupaten Malang yang berpotensi terjadi longsoran lahan, antara lain di Kecamatan Sumbermanjing, Kasembon, Dampit, Ampelgading, Kalipare, Poncokusumo, Dau, Wagir, dan Kecamatan Ngantang. Kecamatan-kecamatan tersebut merupakan daerah dengan tingkat bencana longsor tertinggi di antara daerah lainnya di Kabupaten Malang [2]. Menurut BPBD Kabupaten Malang, riwayat bencana tanah longsor di Kecamatan Ampelgading sejak tahun 2015 sampai 2018 mengalami peningkatan frekuensi kejadian tanah longsor $[2,4]$. Kecamatan Ampelgading

Corresponding author:

Indah Dwi Pratiwi

pratiwi_indah@umm.ac.id

Media Keperawatan Indonesia, Vol 4 No 4, November 2021

e-ISSN: 2615-1669

ISSN: 2722-2802

DOI: $10.26714 / \mathrm{mki} .4 .4 .2021 .264-269$ 
merupakan satu area dengan frekuensi tertinggi yang mengalami bencana tanah longsor. Dampak bencana tanah longsor tidak hanya pada kehilangan nyawa namun juga kerusakan infrastruktur, meliputi banyak rumah masyarakat rusak ringan hingga berat, akses lalu lintas tertutup, dinding sekolah roboh yang mengakibatkan kerugian ratusan juta [4].

Perawat merupakan tenaga kesehatan yang berada pada lini terdepan suatu pelayanan kesehatan dan mempunyai tanggungjawab dan peran yang sangat besar dalam menangani pasien gawat darurat seharihari maupun saat terjadi bencana [5]. Situasi penanganan antara keadaan siaga dan keadaan normal memang sangat berbeda, sehingga perawat harus mampu secara skill dan teknik dalam menghadapi kondisi bencana. Kegiatan pertolongan medis dan perawatan dalam keadaan siaga bencana dapat dilakukan oleh profesi keperawatan [6]. Namun sejauh ini, tingkat pengetahuan dan sikap perawat menghadapi potensi bencana tanah longsor masih belum diidentifikasi secara mendalam. Sehingga, penelitian ini bertujuan untuk menganalisis pengetahuan dan keterampilan perawat dalam menghadapi potensi bencana tanah longsor di Kabupaten Malang.

\section{METODE}

Penelitian merupakan penelitian deskriptik kuantitatif dengan pendekatan survey. Responden dalam penelitian ini berjumlah 20 orang perawat di Puskesmas Ampelgading Kabupaten Malang yang diperoleh secara total sampling.

Peneliti menggunakan instrumen tentang Knowledge, Attitude and Practices (KAP) Disaster Management [5]. Instrumen ini terdiri dari dua domain, meliputi: domain pengetahuan (terdapat 17 item pernyataan tentang definisi, klasifikasi, fase dan kegiatannya terhadap dampak bencana) dan domain sikap (11 item pernyataan tentang kecenderungan sikap akan keterlibatan, fase dan kegiatan pada fase tanggap bencana). Pada domain pengetahuan, skala Guttman digunakan untuk menghitung skor; responden diminta untuk memilih jawaban benar (skor 1) atau salah (skor 0) pada tiap item pernyataan, dengan kemungkinan skor yang diperoleh responden antara 0 - 17. Pada domain sikap menggunakan skala Likert-5-poin, dengan kemungkinan skor yang didapat responden adalah antara 0 - 55 [5].

Instrumen pada penelitian ini telah dinyatakan valid $(0,444)$ dan reliabel (Cronbach's Alpha pada domain pengetahuan adalah 0,7 dan pada domain sikap adalah 0,660) [5].

Penelitian ini telah disetujui oleh Komite Etik Penelitian Kesehatan Universitas Muhammadiyah Malang (KEPK UMM) (Nomor E.5.a/169/KEPK-UMM/VII/2020). Responden yang menyatakan persetujuan setelah menerima penjelasan sebelum penelitian (PSP) dengan mengisi informed consent.

\section{HASIL}

Dari total 20 responden, mayoritas responden (70\%) adalah perempuan dan hampir separuhnya (45\%) berusia 26-35 tahun. Semua responden (100\%) memiliki pendidikan terakhir D3 Keperawatan, hampir setengahnya (40\%) memiiki masa kerja 6-10 tahun, mayoritas (85\%) pernah terlibat dalam kegiatan tanggap darurat bencana, namun lebih dari setengahnya (60\%) tidak pernah terlibat pelatihan manajemen bencana, dan tidak termasuk dalam Tim Gerak Cepat di puskesmas (60\%) (Tabel 1).

Pada domain pengetahuan (Tabel 2), mayoritas responden (75\%) mempunyai pengetahuan yang baik tentang manajemen bencana tanah longsor. Pada domain pengetahuan, $85 \%$ responden mampu menjawab dengan benar definisi dan konsep bencana, semua responden mengetahui bahwa tanah longsor tergolong 
bencana alam, namun hanya seperempat responden yang memahami bahwa kekeringan merupakan jenis bencana yang disebabkan oleh ulah manusia. Dalam penelitian ini juga ditemukan bahwa mayoritas responden memahami bahwa ada lima tahapan manajemen bencana di Indonesia, dan hampir seluruhnya (90\% dari total responden) sepakat bahwa upaya mitigasi dilakukan pada fase pra bencana. Mayoritas responden (95\%) juga mengetahui bahwa pasokan air dan sanitasi dapat memberikan dampak kepada kesehatan; namun 60\% dari keseluruhan responden yang memahami bahwa bencana akan meningkatkan risiko munculnya penyakit.

Dalam domain sikap (Tabel 2), seluruh responden mempunyai sikap yang positif tentang manajeman bencana. Mayoritas responden (95\%) menyatakan setuju bahwa perawat harus dilibatkan dalam melakukan penilaian risiko pada masingmasing daerah dalam fase mitigasi, tentang pentingnya perawat perlu diberikan pemahaman tentang dampak bencana jangka panjang, tentang pentingnya untuk membaca dan memahami rencana penanggulangan bencana pada institusi mereka, pentingnya untuk memasukkan materi atau topik manajemen keperawatan bencana kedalam kurikulum pendidikan kesehatan, dan setuju untuk melakukan kolaborasi antara penyedia darurat dan kesehatan masyarakat benar-benar diperlukan saat pengelolaan korban bencana (Tabel 2).

Pada domain sikap, terdapat temuan yang menarik, dimana separuh responden (50\%) menyatakan merasa sulit untuk berkolaborasi dengan lembaga lain (selain dari bidang kesehatan) dalam pengelolaan korban bencana dan merasa khawatir terhadap dampak negatif bencana (seperti cedera, stress akibat bencana) yang akan terjadi jika menjadi relawan saat terjadinya bencana.

\begin{tabular}{|c|c|c|}
\hline \multicolumn{3}{|c|}{ Karakteristik responden } \\
\hline Indikator & $\mathrm{f}$ & $\%$ \\
\hline \multicolumn{3}{|l|}{ Usia } \\
\hline 23-25 tahun & 4 & 20 \\
\hline 26-35 tahun & 9 & 45 \\
\hline 36-45 tahun & 5 & 25 \\
\hline$>50$ tahun & 2 & 10 \\
\hline \multicolumn{3}{|l|}{ Jenis Kelamin } \\
\hline Laki-laki & 6 & 30 \\
\hline Perempuan & 14 & 70 \\
\hline \multicolumn{3}{|c|}{ Pendidikan Terakhir } \\
\hline D3 Kep & 20 & 100 \\
\hline \multicolumn{3}{|l|}{ Lama Bekerja } \\
\hline$<1$ tahun & 2 & 10 \\
\hline 1-5 tahun & 7 & 35 \\
\hline 6-10 tahun & 8 & 40 \\
\hline$>10$ tahun & 3 & 15 \\
\hline \multicolumn{3}{|c|}{ Pernah Terlibat dalam Kegiatan Tanggap } \\
\hline \multicolumn{3}{|c|}{ Darurat Bencana } \\
\hline Ya & 17 & 85 \\
\hline Tidak & 3 & 15 \\
\hline \multicolumn{3}{|c|}{ Pernah Pelatihan Tentang Manajemen Bencana } \\
\hline Ya & 8 & 40 \\
\hline Tidak & 12 & 60 \\
\hline \multicolumn{3}{|c|}{$\begin{array}{l}\text { Termasuk dalam Tim Gerak Cepat (TGC) di } \\
\text { Puskesmas }\end{array}$} \\
\hline Ya & 8 & 40 \\
\hline Tidak & 12 & 60 \\
\hline
\end{tabular}

Tabel 2

Pengetahuan dan sikap perawat tentang manajemen bencana

\begin{tabular}{lcc}
\multicolumn{3}{c}{ manajemen bencana } \\
\hline \multicolumn{1}{c}{ Indikator } & $\mathrm{f}$ & $\%$ \\
\hline Pengetahuan & & 75 \\
Baik & 15 & 25 \\
Cukup & 5 & 0 \\
Kurang & 0 & \\
\hline Sikap & & 100 \\
Positif & 20 & 0 \\
Negatif & 0 & \\
\hline
\end{tabular}

\section{PEMBAHASAN}

Pada penelitian ini dapat dilihat bahwa mayoritas perawat memiliki pengetahuan yang baik tentang bencana tanah longsor dan kesiapsiagaan dalam menghadapi bencana tanah longsor. Mayoritas perawat menjawab benar pada item pernyataan tentang jenis bencana, kegiatan dan upaya penanggulangan bencana pada tiap-tiap fase/tahapan bencana. Sejalan dengan penelitian terdahulu, dimana tenaga kesehatan (dokter, perawat dan bidan) memiliki pengetahuan yang baik tentang manajemen bencana khususnya terkait 
pengertiannya, dan upaya- upaya yang dilakukan di setiap fasenya $[5,7]$.

Pada penelitian ini, tiga per empat responden mengalami kesulitan dalam memngidentifikasi jenis-jenis bencana. Temuan ini selaras dengan penelitian oleh Susilawati et al yang juga menunjukkan bahwa sebagian besar tenaga kesehatan masih salah dalam membedakan klasifikasi bencana alam, non alam dan bencana social [5]. Pengetahuan adalah faktor utama yang sangat penting untuk kesiapsiagaan. Direja \& Wulan menjelaskan dalam penelitiannya bahwa kurangnya pengetahuan merupakan penyebab utama tingginya korban akibat dinamika proses alam yang terus berlangsung [8]. Hal ini dapat dikaitkan dengan data demografi, bahwa semua perawat memiliki pendidikan terakhir Diploma 3 Keperawatan. Wawan \& Dewi menyatakan bahwa pengetahuan juga dipengaruhi oleh faktor pendidikan secara formal dan sangat erat hubungannya dengan pendidikan yang tinggi maka orang tersebut akan semakin banyak pengetahuan [9]. Semakin tinggi pendidikan perawat maka semakin baik pengetahuan tentang manajemen bencana $[5,10]$.

Dalam penelitian ini, mayoritas perawat memiliki sikap yang positif terhadap kesiapsiagaan menghadapai potensi bencana tanah longsor. Hal ini sejalan dengan penelitian terdahulu yang menemukan bahwa sebagian besar perawat memiliki sikap positif terhadap manajemen bencana dimana terbentuknya sikap yang baik sangat dipengaruhi oleh pengetahuan $[7,8]$. Melihat dari pemenuhan kebutuhan dasar pada fase bencana, responden mayoritas menganggap penting untuk memenuhi kebutuhan dasar korban bencana. Peneliti terdahulu juga menyampaikan bahwa dalam penyelenggaraan penanggulangan bencana pada tahapan tanggap darurat terdapat pemenuhan kebutuhan dasar yang melibatkan perawat [11-13].
Umumnya, sikap perawat dalam penelitian ini mengenai penanggulangan bencana tanah longsor sangat positif. Lebih lebih dari setengah responden sangat setuju bahwa mereka harus terlibat dalam penilaian risiko selama bencana kesiapsiagaan ke daerah masing-masing. Namun, sebagian besar responden menyatakan bahwa ada beberapa kesulitan dalam bekerja sama dengan lembaga LSM lainnya daripada Kementerian Kesehatan selama fase tanggap darurat [12].

Mayoritas responden menganggap penting untuk melibatkan tenaga kesehatan dalam melakukan penilaian risiko bencana. Hal ini sejalan dengan penelitian terdahulu bahwa sikap kesiapsiagaan perawat dimaksudkan untuk menimbulkan kesadaran serta kesiapan perawat dalam mempersiapkan pelayanan kesehatan yang siaga dalam menghadapi bencana [14-16]. Perawat yang memiliki sikap kesiapsiagaan yang baik akan dapat memberikan pelayanan kesehatan yang baik [17]. Sikap tanggap dan responsif terhadap bencana perlu juga ditanamkan, sehingga resiko yang fatal bisa dihindari dan mereka tidak hanya sekedar mengetahui dan memahami tentang bencana, tetapi yang lebih penting adalah bagaimana mereka bisa menghadapi bencana dengan sikap siaga dan responsif sehingga mampu meminimalkan dampak yang lebih parah $[8,18,19]$.

Responden dalam penelitian ini menganggap kolaborasi merupakan bagian terpenting dalam hal kerja sama. Sejalan dengan penelitian Rini et al bahwa perawat perlu bekerja sama dengan potensi lokal (kelompok awam terlatih) seperti relawan dalam melakukan persiapan tanggap bencana dan BPBD dalam program promosi kesehatan untuk meningkatkan kesiapan masyarakat dalam menghadapi bencana $[3,20]$. Responden juga menganggap hal ini bagian terpenting dalam pelayanan kesehatan. Penelitian terdahulu juga menemukan bahwa dampak bencana dapat mengakibatkan menurunnya kualitas hidup masyarakat, termasuk kesehatan [21,22]. 
Hal ini merupakan masalah yang dihadapi setelah terjadinya bencana khususnya pelayanan kesehatan terhadap korban bencana. Penanganan kesehatan korban bencana melalui piranti legal (peraturan, standar) yang sudah dikeluarkan. Salah satunya adalah peraturan yang menyebutkan peran penting puskesmas dalam penanggulangan bencana [21].

\section{SIMPULAN}

Dari penelitian, selain responden mempunyai pengetahuan baik tentang manajemen bencana, mereka juga memiliki sikap yang positif tentang penanggulangan bencana tanah longsor. Perawat memiliki pengetahuan yang baik dan keterampilan dalam penanggulangan bencana dan berkolaborasi dengan pihak lain, termasuk diantaranya adalah ahli lingkungan, ahli epidemiologi, laboratorium, pakar biostatistik, dokter, pekerja sosial, dan perawat lainnya. Perilaku interprofesional diperlukan untuk meningkatkan kesiapsiagaan, dan pemulihan penanggulangan bencana di tingkat lokal, regional, nasional dan secara global.

\section{UCAPAN TERIMA KASIH}

Ucapan terima kasih kepada semua pihak yang telah berkontribusi dalam penelitian ini, sehingga penelitian dapat terlaksana dengan baik.

\section{REFERENSI}

[1] Pinuji S, Savitri AI, Noormasari M, Wijaya D, Kurniawan A. Efektivitas Data Spasial Peta Rupa Bumi Indonesia ( RBI ) dan Openstreetmap dalam Pengambilan Keputusan. J Dialog Penanggulangan Bencana 2019;10:22-9.

[2] Meviana I, Sari UA. Pemetaan Daerah Rawan Longsor Lahan Di Kecamatan Dau, Kabupaten Malang Dengan Menggunakan Pendekatan Geomorfologi. JPIG (Jurnal Pendidik Dan Ilmu Geogr 2017;2:127-34. https://doi.org/10.21067/jpig.v2i2.2493.

[3] Martono M, Satino S, Nursalam N, Efendi F, Bushy A. Indonesian nurses' perception of disaster management preparedness. Chinese J Traumatol - English Ed 2019;22:41-6. https://doi.org/10.1016/j.cjtee.2018.09.002.

[4] BPBD Kabupaten Malang. Data Kejadian Bencana BPBD Kabupaten Malang Tahun 2018. Badan Penanggulangan Bencana Drh Kabupaten Malang 2018.

[5] Susilawati A, Efendi F, Hadisuyatmana S. Gambaran Kesiapan Tenaga Kesehatan Dalam Manajemen Bencana Di Puskesmas Wilayah Rawan Bencana. Indones J Community Heal Nurs ( J Keperawatan Komunitas ) Vol 8, No 1, Agustus 2019 2019;8:11-6.

[6] Putra A, Juwita R, Risna, Alfiandi R, Arnita Y, Iqbal $M$, et al. Peran Dan Kepemimpinan Perawat Dalam Manajemen Bencana Pada Fase Tanggap Darurat. Idea Nurs J 2015;6:25-31.

[7] Aung KT, Nurumal MS, Ahayalimudin NA. Nurses ' knowledge , Attitude and Practices ( KAP ) During Flood Disaster Affected East Coast Region in Malaysia. IOSR J Nurs Heal Sci 2019;8:51-9. https://doi.org/10.9790/19590804085159 .

[8] Direja AHS, Wulan S. Faktor-faktor yang Berhubungan dengan Kesiapsiagaan Tenaga Kesehatan dalam Menghadapi Bencana Gempabumi dan Tsunami. J Dialog Penanggulangan Bencana BNPB 2018;9:10215.

[9] Wawan, Dewi. Teori \& Pengukuran Pengetahuan, Sikap, dan Perilaku Manusia. III. Yogyakarta: Nuha Medika; 2016.

[10] Jamshidi E, Majdzadeh R, Namin MS, Ardalan A, Majdzadeh B, Seydali E. Effectiveness of Community Participation in Earthquake Preparedness: A Community-Based Participatory Intervention Study of Tehran. Disaster Med Public Health Prep 2016;10. https://doi.org/10.1017/dmp.2015.156.

[11] Nurjanah, Sugiharto R, Kuswanda D, BP S, Adikoesoemo. Manajemen Bencana. II. Bandung: Alfabeta; 2013.

[12] Juli SS, Adik W. Upaya Pengurangan Risiko Bencana Pada Kelompok Rentan. J Dialog Penanggulangan Bencana 2019;10:30-8.

[13] Husaini H, Marlinae L, Rahman F, Rosadi D, Anhar VY, Saputra M. Knowledge, attitude and behavior of community in efforts of prevention and control the flood disaster in Kelampaian Ilir village. Int J Appl Bus Econ Res 2016;14.

[14] Setiawati I, Utami Tri G, Sabrian F. Gambaran pengetahuan dan sikap perawat tentang kesiapsiagaan pelayanan kesehatan dalam menghadapi bencana banjir. J Ners Indones 2020;10.

[15] Roder G, Ruljigaljig T, Lin CW, Tarolli P. Natural hazards knowledge and risk perception of Wujie indigenous community in Taiwan. Nat 
Hazards

$2016 ; 81$. https://doi.org/10.1007/s11069-015-2100-4.

[16] Barwani AS Al. Omani Experience in Flash Floods, Disaster Risk Reduction and Water Harvesting. Int J Disaster Risk Reduct 2019;7. https://doi.org/10.26480/mjg.01.2017.32.33.

[17] Farra S, Miller E, Timm N, Schafer J. Improved Training for Disasters Using 3-D Virtual Reality Simulation. West J Nurs Res 2013;35:655-71. https://doi.org/10.1177/0193945912471735.

[18] Nasarudin N, Kasnar S, Suwo R. Analisis Kesiapsiagaan Rumah Tangga Kelurahan Tubo Terhadap Banjir Lahar Dingin Di Sungai Tugurara Ternate. Tunas Geogr 2020;8. https://doi.org/10.24114/tgeo.v8i2.14958.

[19] Juang CS, Stanley TA, Kirschbaum DB. Using citizen science to expand the global map of landslides: Introducing the cooperative open online landslide repository (COOLR). PLoS One 2019;14.

https://doi.org/10.1371/journal.pone.021865 7.
[20] Rini IS, Kristianingrum ND, Widyastikasari R. Relationship Between Level of Disaster Knowledge and Attitude of Landslide Disaster Preparedness in Volunteers "Kelurahan Tangguh" in Malang City. J Nurs Sci 2019;7 No. 2. https://doi.org/10.21776.

[21] Widayatun, Fatoni Z. Permasalahan Kesehatan dalam Kondisi Bencana:Peran Petugas Kesehatan dan Partisipasi Masyarakat (Health Problems in a Disaster Situation : the Role of Health Personnels and Community Participation). J Kependud Indones 2013;8:3752.

[22] Tavan H, Menati W, Azadi A, Sayehmiri K, Sahebi A. Development and validation of a questionnaire to measure Iranian nurses' knowledge, attitude and practice regarding disaster preparedness. J Clin Diagnostic Res 2016;10. https://doi.org/10.7860/JCDR/2016/19894.8 337. 